\title{
Bags, batteries and boxes: A qualitative interview study to understand how syringe drivers are adapted and used by healthcare staff \\ C. J. Vincent \& A. Blandford
}

\begin{abstract}
Syringe drivers are medical devices that are critical for end of life care. They deliver continuous medication over extended periods of time. Their design contributes to the quality of experience for both patients and healthcare professionals. Little research has been published about the factors that influence the usability of this type of equipment for frontline users (i.e. those in direct contact with patients) and how equipment gets introduced. Understanding how syringe drivers are used in practice can help improve the design of equipment. 27 semi-structured interviews were conducted across acute hospitals, community hospitals and hospices (4 organisations in total). All participating organisations used the same type of syringe driver. It was found that frontline staff needed to adapt this equipment to fit the circumstances of use. The analysis provided examples of this happening for aspects relating to the appearance of the device (bags), accessories (batteries) and security (the lockable box).
\end{abstract}

Keywords: Interface, User Computer; Purchasing; Medical Device Design; Palliative Care;

\section{Introduction}

Syringe drivers are widely used for palliative care. These devices are compact boxes that are typically powered by a battery and can be left unattended by healthcare staff. Although patients rely on the effective functioning of these devices for pain relief and have to integrate them into their lives, and although the devices are often left running without professional oversight, there have been no prior studies of how they are used, or of how professionals adapt the devices to address their patients' needs and to remain safe. This paper reports on a study of how equipment gets adapted (e.g. the reconfigurations that occur to support use) and relates this to the process of introducing equipment (purchasing). This builds on a previous paper that reports how those involved in purchasing syringe drivers go about evaluating usability, the challenges that arise, and opportunities for improvement (Vincent and Blandford, 2017). 
Across the UK, most palliative care providers use the same type of syringe driver (for a history see (Graham and Clark, 2005)). The device is used to treat patients when they cannot take oral medication. It can be used to control symptoms and provide pain relief. Palliative care commonly involves the use of an ambulatory syringe driver. This is because patients may be mobile whilst using the device. The current ambulatory device replaced an older piece of equipment (reviewed in (Oliver, 1988)) that was withdrawn due to concerns about a lack of control, difficulty in use and potential for error. The replacement followed the release of a Rapid Response Report (RRR), detailing the potential for confusion to arise when setting the rate.

"While the majority of syringe drivers and pumps used in healthcare have rate settings in millilitres $(\mathrm{ml})$, some older types of ambulatory syringe drivers have rate settings in millimetres ( $\mathrm{mm}$ ) of syringe plunger travel. This is not intuitive for many users and not easy to check." (NPSA, 2010)

Although there was a need to replace the old equipment, there was a limited choice in the marketplace; some trusts reported that they had little choice but to use a single type of technology. The focus of this study is on the ways in which the equipment was adapted for use across multiple settings (acute hospitals, community hospitals, hospices and homes), and how this relates to the original process of introducing it. The circumstances surrounding the introduction of this equipment provide an opportunity to learn how the needs of multiple local organisations could have been met, based on the capabilities of a generic piece of technology.

\section{Equipment replacement and socio-technical systems (STS)}

The syringe driver was provided with an agreed default configuration (as recommended in NPSA, 2004). This means that the functionality and appearance of the device is the same regardless of where the device is being used. However, in this domain the nature of work is characterised by relatively small groups of individuals acting independently, in different ways, across different settings (see Table 1). The nurses set up, activate and replenish the drivers individually but are part of a larger team that develops a shared view on practice. For example some nurses may use the syringe driver battery compartment lid to lever out the battery. This is not described in the instruction manual and reflects a local variation in use. Such variation may be a result of an insight that has been shared within a group or a response to a specific challenge that a group faces. For example if a syringe driver is used outdoors then protection may be added to keep the device dry. If a large volume of solution is required then two devices may be used. If the device is used with children, a parent may be asked to perform similar checks to a clinician (e.g. checking that the device is running). 
Table 1: Different environments of use

\begin{tabular}{|c|c|c|}
\hline Environment & $\begin{array}{l}\text { Use of device by healthcare } \\
\text { professional }\end{array}$ & Customisation \\
\hline Home & $\begin{array}{l}\text { Nurse visits home to set-up / } \\
\text { replenish device. Device kept in a } \\
\text { lockbox. Device left unattended. } \\
\text { Nurse needs to travel to attend to } \\
\text { patient or device. }\end{array}$ & $\begin{array}{l}\text { Device used with lockbox. Device } \\
\text { sometimes used with bag. Staff need to } \\
\text { check the level of power in the battery } \\
\text { and may keep spares. The appearance of } \\
\text { the device should reflect the home } \\
\text { environment. }\end{array}$ \\
\hline $\begin{array}{l}\text { Community } \\
\text { Hospital }\end{array}$ & $\begin{array}{l}\text { In this study the community } \\
\text { hospital was used as a hub for the } \\
\text { nurses working in patient homes. }\end{array}$ & $\mathrm{N} / \mathrm{A}$ \\
\hline Hospice & $\begin{array}{l}\text { Nurse checks pump on a regular } \\
\text { basis. Device kept in a lockbox. } \\
\text { Device may or may not be } \\
\text { attended. }\end{array}$ & $\begin{array}{l}\text { Device used with lockbox. Device may be } \\
\text { positioned under a bed or under pillow. } \\
\text { The device may be used with a docking } \\
\text { station / external power supply. The } \\
\text { device needs to support regular checks / } \\
\text { monitoring. }\end{array}$ \\
\hline Acute Hospital & $\begin{array}{l}\text { Nurse checks pump on a regular } \\
\text { basis. Device kept in a lockbox. } \\
\text { Device likely to be attended. Device } \\
\text { may be substituted with another } \\
\text { type. Device training provided by } \\
\text { training staff working in the } \\
\text { hospital. }\end{array}$ & $\begin{array}{l}\text { Device used with lockbox. Device is part } \\
\text { of a centrally managed equipment } \\
\text { library. Device positioned at bedside. The } \\
\text { device could be used with a docking } \\
\text { station / external power supply. The } \\
\text { device needs to support regular checks / } \\
\text { monitoring. }\end{array}$ \\
\hline
\end{tabular}

In this way teams find their own ways of working in order to promote efficiency and job satisfaction. Optimisation occurs beyond the level of the individual but within the level of the team (Trist and Bamforth, 1951; Trist et al., 1963). This topic is very relevant for healthcare as there is a debate relating to the benefits that customisation provides (Obradovich and Woods, 1996), and little attention has been paid to how well the practices of customising fit with wider processes and controls, for example the medical device regulations that seek to define normal conditions of use which remain constant over time (Randell, 2003).

For example (as in this case), the equipment may be introduced in a very generic way (e.g. mandated by an overarching body); however, socio-technical systems theory (STS) suggests that there may be benefits in smaller groups adapting and taking responsibility for it (e.g. the principle of responsible autonomy (Amble, 2013)). In the homecare environment this could involve customising the device to make it look discreet (O'Kane et al., 2015). In the hospital context equipment could be modified beyond the original design intent, as per accounts relating to barcoding systems (Koppel et al., 2008), alarm settings (Watson et al., 2004), physiological monitors (Cook and Woods, 1996) infusion pumps (Obradovich and Woods, 1996) and glucometers (Furniss et al., 2015).

In domains other than healthcare (e.g. software), the literature generally paints a positive picture regarding the role of adaptation and customisation. Adaptation can be broken down into three categories. Users can change the structure of work to accommodate new technology [fitting], they can workaround what they 
see as misalignments; and they can augment work in light of new technology (Gasser, 1986). These behaviours are seen as a vehicle for improving practice and confronting the problems that can arise over time (Mackay, 1990; Rogers, 1994). Changes can be acknowledged, fed into design and used to inform future generations of technology.

Research is required to understand the process of "mutual adaptation between tool and context" (Bikson and Eveland, 1996) as findings affect how equipment is managed (e.g. embracing customisation or seeking to avoid it) and the general approach to introduction. For example, some of these behaviours might create additional risks. Obradovich and Woods (1996) state that when considered in a broader context adaptations may be brittle, produce unanticipated side effects or create new paths to failure. A more positive account is provided by Cook and Woods (1996) - e.g. "system tailoring clearly enhances some aspects of performance"; however, there remains uncertainty around the benefit that customisation provides and how it should be managed.

This situation is complicated by the different types of modification that can occur. Randell (2003) gives examples of different types of medical device customisation, including: those aiming to overcome limitations (e.g. short term solutions such as resetting a device); those aiming to provide for ease of use (pen and paper adaptations); and those that change procedures around technology. The different types of adaptation can result in varying benefits, integrate with existing processes to varying degrees and may or may not be productive.

There is therefore a degree of uncertainty about how adaptation occurs and what benefit it provides. For palliative care, there have been no accounts of this type of behaviour. This study complements existing understanding regarding the safe and efficient use of syringe drivers (Costello et al., 2008; Cruickshank et al., 2010; McCormack et al., 2001; West, 2014); it can also inform the approach to the future introduction of technology. For example, investigation focused on a specific type of technology can be used to build theories outlining the relationship between user-device interactions and system wide consequences (for example technology acceptance) as in (Sharples et al., 2012). If we understand the types of modification that occur to support productivity we can design, integrate and manage technology in a way that supports patients and healthcare staff. A holistic view (understanding interactions between people, technology, tasks, organisations and environment) helps provide a safer and more productive workplace (Smith and Carayon, 1989) and frameworks such as SEIPS (the Systems Engineering Initiative for Patient Safety) show the benefit of such an approach (Carayon, 2009; Carayon et al., 2006; Carayon and Smith, 2000; Carayon et al., 2014).

In the context of this study, understanding these broader relationships potentially impacts on the theories that underpin the design of medical technology with the consequence that better tools can be provided. 


\section{Overview of the research setting}

In the UK, the home environment is the preferred location for end of life care. In this case healthcare professionals set up a syringe driver and it is left with the patient and checked daily. If there are any problems with the device then the patient or family member can contact a nurse. The syringe driver can also be used in an in-patient setting (for example within a hospice or community hospital), as summarised in Table 1. In these cases the driver can be checked at regular intervals (for example every hour or every four hours); the frequency depends on the type of hospital and ward in which the treatment is being administered. If used in an acute hospital, the arrangements are similar; however, management of the device overlaps with the wider process in the hospital (e.g. managed as part of a centralised equipment library). These different locations provide contrasting focuses of study, and make it more likely that a degree of customisation will be required dependent on the location (see Table 1). If a standard piece of equipment is introduced then it can be hard to satisfy user needs across all of these different contexts (e.g., should it be made to look like a piece of medical equipment or a should it be designed to blend into the home environment)? The need for customisation as defined is therefore an important topic for investigation; on one hand limiting customisation offers potential safety benefits (control and consistency), on the other hand it risks providing a tool that does not meet the needs of patients and healthcare professionals. 


\section{Methods}

A qualitative interview study involving NHS staff was conducted based on the following procedure.

\section{Procedure}

The study involved semi-structured interviews (27 participants across an acute hospital, a community hospital, a hospice and a trust office [for community care]). Acute hospitals and community hospitals are different in terms of the size of the facility (community hospitals are smaller), range of procedures that can occur and way in which equipment is managed.

Participants across multiple sites were contacted via a regional Clinical Research Network (CRN) and were approached in parallel. All interviews focused on the introduction and use of the aforementioned syringe driver, with the aim of better understanding their work practices.

Data were analysed using thematic analysis, a qualitative method designed to support the identification, analysis and reporting of patterns (themes) (Braun and Clarke, 2006). The method was chosen, as it is independent of theory and offers a flexible and accessible approach to the analysis of qualitative data.

Ethical permission was obtained via a university departmental research ethics committee. Additional permissions were obtained as per the Health Research Authority (HRA) process for a qualitative study involving staff in the UK National Health Service (i.e. research governance was granted by the healthcare trusts involved in the study). All data were anonymised.

The study was based on one of two topic guides, such that questions were chosen based on the circumstances of the participant (Table 2). Where possible, they were tailored to a participant, both in terms of the topic guide that was chosen and the decision to omit questions that were not relevant. The topic guide was chosen prior to the interview based on the extent to which the participant had been involved in the introduction or purchasing of the syringe driver. For one guide (purchasers), interviews addressed 7 topics, based around the equipment lifecycle, with an emphasis on evaluating equipment during purchasing (Table 3). For the other guide (device users), the interviews addressed 5 topics; less emphasis was placed on the purchasing of equipment and more on the experience of use (Table 4). Two topic guides were necessary as not all users were involved in purchasing. The results reported in this paper draw mainly on the interviews conducted using the topic guide for device users.

Both topic guides aimed to balance the need for brevity whilst focusing potential insight. The guides contained a default plan for the interviews, but topics could be covered in a different order, depending on how participants responded. 
Informed consent was collected from participants. All participants agreed to interviews being audio recorded. The audio recorder was clearly visible to participants during interviews. Pictures of equipment or accessories were taken with permission of those who were involved.

Table 2: Participants

\begin{tabular}{|c|c|c|c|c|}
\hline Profile & $\begin{array}{l}\text { Topic } \\
\text { guide }\end{array}$ & Organisation & Profile & $\begin{array}{l}\text { Involvement in } \\
\text { purchasing }\end{array}$ \\
\hline 1 & $\begin{array}{l}\text { Device } \\
\text { users }\end{array}$ & Hospice & $\begin{array}{l}\text { Community } \\
\text { practitioner (team } \\
\text { lead) }\end{array}$ & $\mathrm{L}$ \\
\hline 2 & $\begin{array}{l}\text { Device } \\
\text { users }\end{array}$ & Hospice & Staff nurse & $\mathrm{L}$ \\
\hline 3 & $\begin{array}{l}\text { Device } \\
\text { users }\end{array}$ & Hospice & District nurse & $\mathrm{L}$ \\
\hline 4 & $\begin{array}{l}\text { Device } \\
\text { users }\end{array}$ & Hospice & Hospice manager & $\mathrm{L}$ \\
\hline 5 & $\begin{array}{l}\text { Device } \\
\text { users }\end{array}$ & Hospice & Staff nurse & $\mathrm{L}$ \\
\hline 6 & $\begin{array}{l}\text { Device } \\
\text { users }\end{array}$ & Hospice & Staff nurse & $\mathrm{L}$ \\
\hline 7 & $\begin{array}{l}\text { Device } \\
\text { users }\end{array}$ & Hospice & Staff nurse & $\mathrm{L}$ \\
\hline 8 & $\begin{array}{l}\text { Device } \\
\text { users }\end{array}$ & Community hospital & $\begin{array}{l}\text { Clinical nurse } \\
\text { specialist }\end{array}$ & $\mathrm{L}$ \\
\hline 9 & $\begin{array}{l}\text { Device } \\
\text { users }\end{array}$ & Community hospital & $\begin{array}{l}\text { Clinical nurse } \\
\text { specialist }\end{array}$ & $\bar{L}$ \\
\hline 10 & $\begin{array}{l}\text { Device } \\
\text { users }\end{array}$ & Community hospital & $\begin{array}{l}\text { Clinical nurse } \\
\text { specialist }\end{array}$ & $\mathrm{M}$ \\
\hline 11 & Purchasers & Community hospital & $\begin{array}{l}\text { Clinical nurse } \\
\text { specialist }\end{array}$ & $\mathrm{H}$ \\
\hline 12 & $\begin{array}{l}\text { Device } \\
\text { users }\end{array}$ & Community hospital & Nurse & $\bar{L}$ \\
\hline 13 & $\begin{array}{l}\text { Device } \\
\text { users }\end{array}$ & Community hospital & Nurse - team lead & $\bar{L}$ \\
\hline 14 & $\begin{array}{l}\text { Device } \\
\text { users }\end{array}$ & Community hospital & Macmillan nurse & $\mathrm{M}$ \\
\hline 15 & $\begin{array}{l}\text { Device } \\
\text { users }\end{array}$ & Community hospital & Assistant practitioner & $\mathrm{M}$ \\
\hline 16 & $\begin{array}{l}\text { Device } \\
\text { users }\end{array}$ & Community hospital & Macmillan nurse & $\mathrm{L}$ \\
\hline 17 & Purchasers & Acute hospital & $\begin{array}{l}\text { Palliative care nurse } \\
\text { specialist }\end{array}$ & $\mathrm{M}$ \\
\hline 18 & Purchasers & Acute hospital & $\begin{array}{l}\text { Consultant for } \\
\text { palliative care }\end{array}$ & $\mathrm{H}$ \\
\hline 19 & $\begin{array}{l}\text { Device } \\
\text { users }\end{array}$ & Acute hospital & $\begin{array}{l}\text { Medical device } \\
\text { educator }\end{array}$ & $\mathrm{M}$ \\
\hline 20 & $\begin{array}{l}\text { Device } \\
\text { users }\end{array}$ & Acute hospital & Charge nurse & $\mathrm{M}$ \\
\hline 21 & $\begin{array}{l}\text { Device } \\
\text { users }\end{array}$ & Acute hospital & $\begin{array}{l}\text { Staff nurse; ward } \\
\text { manager }\end{array}$ & $\mathrm{M}$ \\
\hline 22 & $\begin{array}{l}\text { Device } \\
\text { users }\end{array}$ & Acute hospital & Staff nurse & $\mathrm{L}$ \\
\hline 23 & $\begin{array}{l}\text { Device } \\
\text { users }\end{array}$ & Acute hospital & $\begin{array}{l}\text { Nurse general medical } \\
\text { ward }\end{array}$ & $\mathrm{M}$ \\
\hline
\end{tabular}




\begin{tabular}{|l|l|l|l|l|}
\hline Profile & $\begin{array}{l}\text { Topic } \\
\text { guide }\end{array}$ & Organisation & Profile & $\begin{array}{l}\text { Involvement in } \\
\text { purchasing }\end{array}$ \\
\hline 24 & Purchasers & Acute hospital & $\begin{array}{l}\text { Palliative care } \\
\text { specialist }\end{array}$ & $\mathrm{H}$ \\
\hline 25 & Purchasers & $\begin{array}{l}\text { Trust (community } \\
\text { role) }\end{array}$ & $\begin{array}{l}\text { End-of-life care } \\
\text { facilitator }\end{array}$ & $\mathrm{H}$ \\
\hline 26 & $\begin{array}{l}\text { Device } \\
\text { users }\end{array}$ & $\begin{array}{l}\text { Trust (community } \\
\text { role) }\end{array}$ & $\begin{array}{l}\text { End of life care } \\
\text { facilitator }\end{array}$ & $\mathrm{M}$ \\
\hline 27 & $\begin{array}{l}\text { Device } \\
\text { users } \\
\text { role) }\end{array}$ & $\begin{array}{l}\text { Pharmaceutical } \\
\text { medicines } \\
\text { information, } \\
\text { education and training }\end{array}$ & $\mathrm{M}$ \\
\hline
\end{tabular}

NOTE: Involvement in purchasing: L = Low: very little or no involvement, $\mathrm{M}$ = Medium: limited involvement (e.g. providing feedback), $\mathrm{H}=$ High: substantial involvement. 


\begin{tabular}{|c|c|c|}
\hline Topic & Description & Representative question \\
\hline $\begin{array}{l}\text { T1: Personal } \\
\text { Background }\end{array}$ & $\begin{array}{l}\text { Interviewee role and } \\
\text { responsibility. }\end{array}$ & $\begin{array}{l}\text { What is your job, what does it } \\
\text { involve, how long have you } \\
\text { been doing it for and what is } \\
\text { your background / } \\
\text { experience? }\end{array}$ \\
\hline $\begin{array}{l}\text { T2: Example } \\
\text { Purchasing Project }\end{array}$ & $\begin{array}{l}\text { Example purchasing } \\
\text { project including, trigger, } \\
\text { who was involved, } \\
\text { intended user, need for } \\
\text { new equipment. }\end{array}$ & $\begin{array}{l}\text { I would like you to tell me } \\
\text { about a recent purchasing } \\
\text { project relating to an infusion } \\
\text { device. [prompts where } \\
\text { necessary] }\end{array}$ \\
\hline T3: Process & $\begin{array}{l}\text { Awareness, interpretation, } \\
\text { utility and relevance of } \\
\text { purchasing guidelines, } \\
\text { process and authority. }\end{array}$ & $\begin{array}{l}\text { Did you follow an agreed } \\
\text { process? }\end{array}$ \\
\hline $\begin{array}{l}\text { T4: Budget and } \\
\text { Selection }\end{array}$ & $\begin{array}{l}\text { Cost, leasing, purchasing } \\
\text { options. }\end{array}$ & $\begin{array}{l}\text { What budget was the } \\
\text { equipment purchased on and } \\
\text { why? }\end{array}$ \\
\hline $\begin{array}{l}\text { T5: Advice on } \\
\text { Equipment } \\
\text { Interactivity }\end{array}$ & $\begin{array}{l}\text { Awareness of sources of } \\
\text { support re device } \\
\text { interactivity. }\end{array}$ & $\begin{array}{l}\text { Who did you go to for advice } \\
\text { on the suitability of the } \\
\text { equipment? }\end{array}$ \\
\hline $\begin{array}{l}\text { T6: Introduction of } \\
\text { Equipment }\end{array}$ & $\begin{array}{l}\text { Phased } v \text { incremental } \\
\text { introduction, length of } \\
\text { process. }\end{array}$ & $\begin{array}{l}\text { Was there a phased } \\
\text { introduction of the } \\
\text { equipment or did it get } \\
\text { deployed in one go? }\end{array}$ \\
\hline $\begin{array}{l}\text { T7: Agreement, } \\
\text { Reconciliation and } \\
\text { Expectations }\end{array}$ & $\begin{array}{l}\text { Reaching a consensus, } \\
\text { trade-offs, outcome v } \\
\text { expectation, what did / did } \\
\text { not work well. }\end{array}$ & $\begin{array}{l}\text { Did everyone agree on your } \\
\text { chosen solution? }\end{array}$ \\
\hline
\end{tabular}


Table 4: Interview topics for those affected by purchasing decisions on infusion devices (i.e., users)

\begin{tabular}{|c|c|c|}
\hline Topic & Description & Representative question \\
\hline $\begin{array}{l}\text { T1: Personal } \\
\text { Background }\end{array}$ & $\begin{array}{l}\text { Interviewee role and } \\
\text { responsibility. }\end{array}$ & $\begin{array}{l}\text { What is your job, what does it } \\
\text { involve, how long have you } \\
\text { been doing it for and what is } \\
\text { your background / experience? }\end{array}$ \\
\hline $\begin{array}{l}\text { T2: Devices } \\
\text { Used }\end{array}$ & $\begin{array}{l}\text { Example of an infusion } \\
\text { device that they used; } \\
\text { naming conventions; context } \\
\text { of use; alternative devices. }\end{array}$ & $\begin{array}{l}\text { I would like you to tell me } \\
\text { about the types of infusion } \\
\text { device that you use. }\end{array}$ \\
\hline $\begin{array}{l}\text { T3: } \\
\text { Involvement in } \\
\text { Purchasing }\end{array}$ & $\begin{array}{l}\text { Experiences of being } \\
\text { involved in the purchasing of } \\
\text { the infusion device, and/or } \\
\text { recollection of introduction. }\end{array}$ & $\begin{array}{l}\text { Were you involved in the } \\
\text { purchasing / selection of the } \\
\text { device? If so please describe } \\
\text { what happened? }\end{array}$ \\
\hline $\begin{array}{l}\text { T4: Suitability } \\
\text { of Equipment. }\end{array}$ & $\begin{array}{l}\text { Likes / dislikes, needs, } \\
\text { issues, comparisons with } \\
\text { other equipment. }\end{array}$ & $\begin{array}{l}\text { Is it [the device] suitable for the } \\
\text { job that you are doing? }\end{array}$ \\
\hline $\begin{array}{l}\text { T5: Networks } \\
\text { and Advice }\end{array}$ & $\begin{array}{l}\text { Awareness of sources of } \\
\text { support and advice; } \\
\text { influences on selection. }\end{array}$ & $\begin{array}{l}\text { Who would you go to for advice } \\
\text { on the device? }\end{array}$ \\
\hline
\end{tabular}




\section{Coding process}

Analysis was conducted after all interviews were complete. Data from interviews were transcribed and loaded into ATLAS.ti (Scientific Software Development $\mathrm{GmbH}$ ). Atlas.ti is qualitative data analysis software. Transcripts are systematically analysed to uncover the phenomena that are contained within data. This occurs through a process of coding and annotation where the interview transcripts are studied and sections of content labelled (coded) in order to determine relationships and themes. The software supports thematic analysis (Braun and Clarke, 2006), an approach chosen because it balances the need for rigour with flexibility to allow for a range of patterns and phenomena to emerge. Thematic analysis has been successfully used to account for phenomena underpinning medical device design, development, purchasing and use (e.g. (Cafazzo et al., 2012; Money et al., 2011; Vincent et al., 2014)); we were expecting the analysis to provide a similar degree of insight in this case.

As part of the thematic analysis, the first author conducted a process of inductive coding. Inductive coding is a process that involves labelling parts of the transcript (typically one or two sentences) with a heading such as "training". These labels (or codes) are combined to form patterns of response or meaning. This means that the findings emerged from the data - i.e. there was no preconceived hypothesis.

Over progressive interviews, the codes were combined, revised and simplified (as in phase three of (Braun and Clarke, 2006)). Transcripts were analysed successively in the order of the interviews. A measure of the number of codes generated at varying points in the analysis was taken (see supplementary data). This determined the degree to which the coding set was complete. For example, if the process of reading a transcript generated no new insight then no new codes would be produced. Monitoring the number of codes enabled consideration of the cost of additional analysis versus the utility of the likely insight. When the analysis was complete 84 codes had been defined. The generation of new codes reached a plateau from interview 17 onwards (27 transcripts were analysed), giving confidence that saturation had been reached. This is in line with other studies (Guest et al., 2006).

\section{Results}

In all cases, the syringe driver had been used for some time (more than a year). Due to the varied contexts in which the device was used, there had been a need to tailor the device according to local circumstances. The introduction of a generic technology could only go so far in anticipating the needs of those working in different environments (home, hospice, community hospital, acute hospital). There was a need to respond to the different environments in which the device was used and adjust accordingly. This was under the control of the frontline staff. Three themes emerged; they related to a process of customisation 
in which staff modified the appearance of the device (e.g. by using bags or pillows to disguise the device), selective use of certain accessories (e.g. batteries and syringes) and device security (use within a lockbox). Results are discussed in terms of their impact on the way that equipment is introduced and managed. Associated quotations are provided in Table 5 (indexed by an OBS [observation] reference as provided in the main text).

\section{The use of bags and pillows to disguise the device}

Participants were sensitive to the reaction of the patient, friends and family to the sight of the syringe driver. Staff reported their concerns that others would think that by providing a syringe driver end of life was going to occur soon.

The appearance of the device was being changed or disguised. This could occur by placing it in a custom made bag or by hiding it in other ways. This varied dependent on the location and circumstances but was observed across multiple sites. For example, if used in an in-patient (hospital) setting, staff concealed the device or disguised it under a pillow so that it did not upset visitors or remind the patient of their treatment. In this case the patient was generally bed bound. Staff reported the need for quiet and discreet equipment, with the caveat that the patient did not forget that they were attached to the device.

Some patients would use the device in hospital whilst mobile. In this case staff disguised it by placing it in a disposable bag which matched the patient's clothing. This could help conceal the device and avoid making it apparent to family and friends. Another option including placing the device in a dressing gown; however, the size of the lockbox could prevent this. In both cases staff did not believe that it was possible to use the manufacturer supplied bag (Figure ), due to difficulties in keeping it clean. The bag was seen to be incompatible with cleaning processes or deemed as "single use".

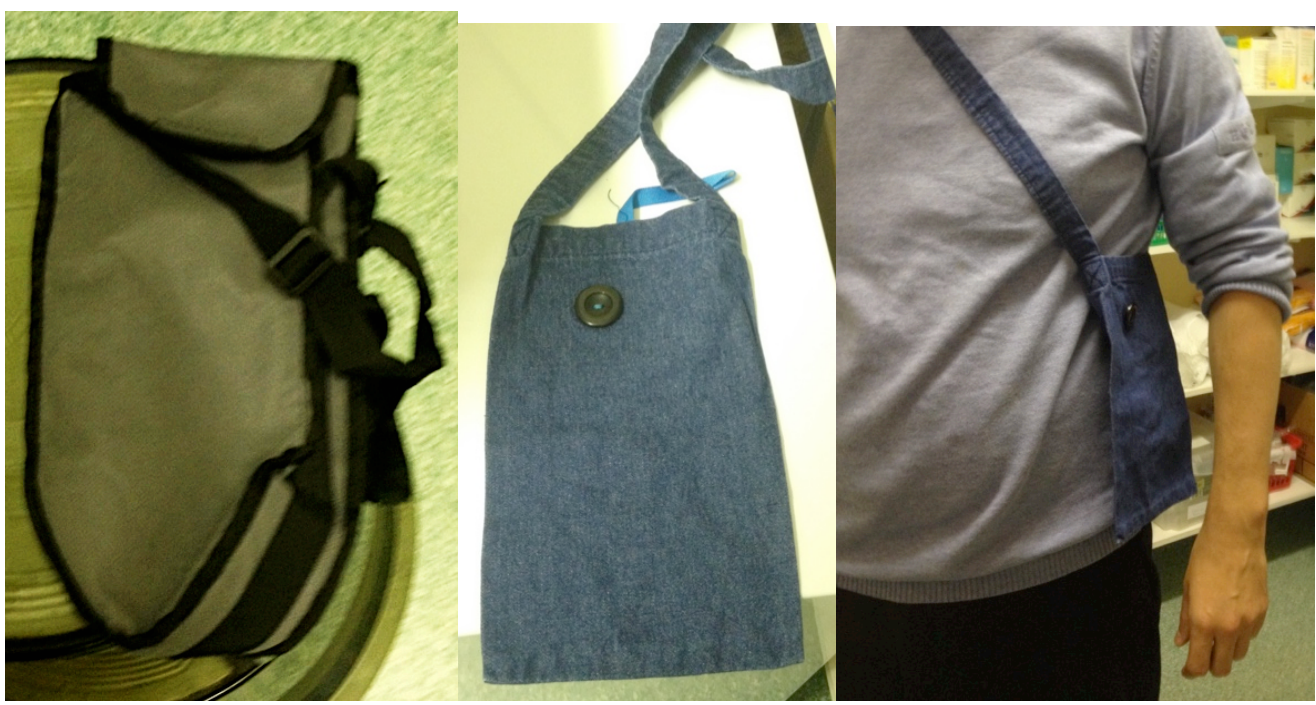

Figure 1: The bag supplied by the manufacturer (left) and the remade bag (centre and right). See also http://www.webcitation.org/6kJwikvNl 
In the home environment the bags used to carry the equipment had been replaced by custom-made alternatives. In this environment it was more usual for people to walk around whilst carrying the device. The new bags were styled in a different way and looked more attractive (Figure - centre and right). They were produced by volunteers rather than being purchased. Charities were prepared to create the bags for free and they could be personalised in a way that wasn't possible with the manufacturer supplied bags (OBS1).

Staff had taken ownership of the limitations of the existing bag (which they had restricted numbers of, could not wash, and could not reliably locate). They had worked with patients and community groups to make their own bags. The bags took varying forms. They also appropriated items like handbags and drawstring bags to provide a degree of familiarity and make the device fit with preference and lifestyle.

The converse situation was where factors outside the control of the nursing staff were impacting the appearance of the equipment. For example, staff mentioned that they liked the fact that the new syringe driver was discreet. They contrasted their experience with it with times when they unexpectedly encountered equipment that was not discreet. For example, in the hospice context, staff reported their concerns about patients arriving with larger bulky syringe drivers, of the type used in a hospital environment. One participant referred to this machine as a "monster" (OBS2).

\section{Selective use of batteries and syringes}

The device was used with multiple accessories including: a lockable box (lockbox) - (Figure ), keys, batteries, drugs, syringes, lines, wipes and needles. In the homecare context these items were kept in a bag that was located near to the syringe driver. Adaptations were identified relating to the use of these accessories, for example the batteries used to power the device and the syringes used to dispense drugs. 


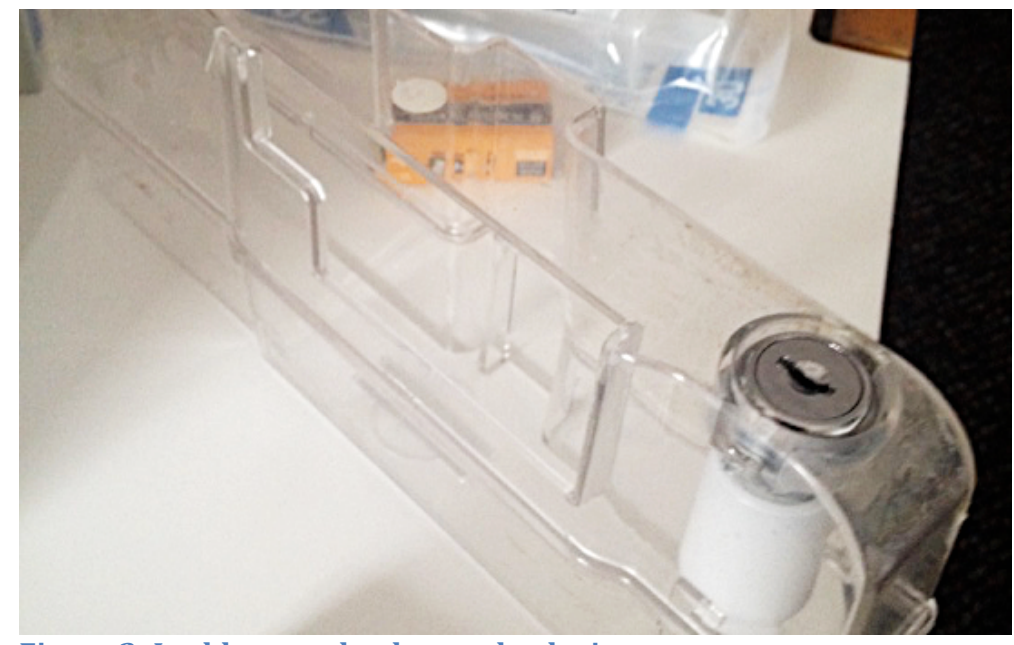

Figure 2: Lockbox used to house the device

The choice of battery was important in that if a battery was of poor quality it would run out rapidly, the device would alarm and eventually stop. This would cause the treatment to end early and require staff to attend. Generally speaking, batteries would last for three days and they were replaced well ahead of time. The level of power was checked prior to starting the device. However there were a variety of batteries in use and the performance of the battery was hard to predict (OBS 3).

Given a concern about the potential for the battery to run out, staff had compensated by adapting and supplementing their routine. In one unusual case, they had asked the patient to help by getting them to change the battery themselves (OBS4).

Other behaviours included staff carrying spare batteries with them and keeping up to three spare batteries in the accessory case. In the hospice environment, they had access to a local supply of batteries and would differentiate between "good" batteries and others based on appearance and manufacturer name. In this case, a supply of inferior batteries had confused the situation (OBS5; OBS6).

A similar situation was observed relating to other components. There were restrictions on the types of syringe that could be used with the device. For example, a $50 \mathrm{~mL}$ syringe would not fit into the lockbox. Using such a syringe could be preferable as it provided extra diluent, which was generally in the interest of the patient. It was not possible to combine this syringe with the device whilst using a lockbox, so this type of syringe was not used. Staff suggested that what was possible with the lockbox was quite restrictive. For example some staff thought that nothing larger than a $30 \mathrm{~mL}$ syringe could be used (OBS 7).

Similar constraints occurred in terms of the positioning of the syringe. For example, if a $30 \mathrm{~mL}$ syringe was loaded in a certain way then the lockbox would not close or the device would alarm. This could occur if the collar of the syringe was not at the correct angle (OBS 8). In this case training and word of mouth had allowed staff to adapt the way that they set up the device to stop this from 
happening. For example, staff reported carefully checking the position of the syringe prior to closing the box.

\section{Security of the device and use with a lockbox}

The syringe driver that is being used by the nurses includes controls designed to stop unauthorised access and tampering. The previous piece of equipment had typically been uncontrolled, in that the entire contents of the syringe could be dispensed as a result of tampering (although there was an option to use the device with a lockbox). That device did not have a comprehensive event log (way of recording device actions such as a change in rate). This meant that if a device was emptied in one go it could be impossible to fully understand what had happened. One of the reasons for introducing the replacement piece of equipment and accompanying lockbox was concerns about this lack of control (OBS 9).

Unlike the previous equipment, the new equipment is contained within a lockbox (Figure ). The lockbox provides a degree of security in that it makes it difficult for others to access the drugs contained within the syringe driver or tamper with the syringe. The downside of the lockbox is that it makes the device bulky and could complicate legitimate access (OBS10; OBS11). At the same time the boxes were being dropped and becoming cracked (OBS12).

Staff suggested a need to make the box softer and more robust (like a mobile phone case). This was because the box itself could be placed under a bed pillow (to conceal the combination of device and box). Even when the lockboxes worked as designed, there were differences in approach to storing the key used to open the lockbox. It could be kept near to the device, stored personally, and/or stored centrally (e.g. with other ward keys or in a key box). The situation was particularly complicated in the home environment.

When used in the home context, staff would typically leave the key with the device but hide it in an inaccessible place. When the device had been introduced, it was decided that as spare drugs were kept in the home, trust was required. This trust could be reflected in the decision to leave the key with the device. If staff were concerned about the potential for diversion of drugs, or uncontrolled use of the driver, they could keep the key on their person. They could also choose not to allow care to occur in the home (OBS13).

It was easier to keep the key near the device rather than with a member of staff as multiple people would be involved in patient care. By storing a key with the device there was a degree of flexibility in that if other staff needed to open the device, they could do so. Therefore, in the homecare context staff were leaving the key with the device (most of the time). They hid the key in a variety of places. They could sometimes lose the key (OBS14).

To compensate for this in one case two keys were hidden. Keys were also hidden in a place where it was impossible for a member of staff not to discover them (e.g. discovery of the key was implicit in the procedure for setting up the device). 
Spare keys were also kept in a central location. Some keys were adapted using coloured caps, to make them as visible as possible. The meaning placed in the key was therefore variable and there was a balance to be achieved between the protection that the lock provided and concerns about impeding care. The box therefore provided an important function, but as with the batteries and syringes, there had been a need for adaptation. 
Table 5: Quotations from interviews. Participant numbers are included after each quotation - (see Table 2).

\begin{tabular}{|c|c|c|}
\hline Recommendation & Quotation & REF \\
\hline 1 Provide custom made bag. & $\begin{array}{l}\text { "they can carry it in a bag which is really good... } \\
\text { and what bag? } \\
\text { ummm patients tend to come up with their own, } \\
\text { they tend to personalise it really, we have had } \\
\text { quilters, we have had like craft people, that have } \\
\text { made us bags, umm and the patients love it..." (26) }\end{array}$ & OBS1 \\
\hline $\begin{array}{l}2 \text { Make the device small and } \\
\text { attractive. }\end{array}$ & $\begin{array}{l}\text { "To be honest at the moment I can't think of the } \\
\text { name, they were just monsters. We actually had } \\
\text { one sent home over here by mistake once with a } \\
\text { patient from [hospital name]. And everybody here } \\
\text { was panicking because they didn't know what this } \\
\text { monster was or how they could turn it off" (5) }\end{array}$ & OBS2 \\
\hline $\begin{array}{l}3 \text { Improve battery technology } \\
\text { and include checks and controls } \\
\text { that avoid the need for } \\
\text { replacement of the battery during } \\
\text { treatment. }\end{array}$ & $\begin{array}{l}\text { "Yes it will start bleeping before the battery runs } \\
\text { out and says something like battery low. But we } \\
\text { always try when we leave to make sure that } \\
\text { there's enough battery to last until the next visit. } \\
\text { But sometimes it will just drain for no reason." (3) } \\
\text { "If they ring up and say, oh you know, it says } \\
\text { batteries low, they can sometimes change it } \\
\text { themselves. I mean, the lady we've got has been on } \\
\text { it for a long time. So it did do that and she was able } \\
\text { to change the battery herself..." (3) } \\
\text { "...batteries, I mean you need a good battery in it. } \\
\text { You know I think there has been an instance } \\
\text { where they bought the cheaper batteries. Well } \\
\text { they run out [of power] in no time." (5) } \\
\text { "So then now we've had a memo saying always use } \\
\text { the [battery supplier] ones that are specifically } \\
\text { bought for it..." (7) }\end{array}$ & $\begin{array}{l}\text { OBS3- } \\
\text { OBS6 }\end{array}$ \\
\hline $\begin{array}{l}4 \text { Provide for compatibility across } \\
\text { commonly used accessories } \\
\text { (syringes); provide feedback at } \\
\text { time of setup; provide reliable } \\
\text { attachment for the syringe. }\end{array}$ & $\begin{array}{l}\text { “...30. It only likes this kind of syringe. Any other } \\
\text { syringe, it doesn't really like to recognise it. And in } \\
\text { my experience, if you put a different one in and } \\
\text { you get it to go; it always bleeps at you about an } \\
\text { hour later. But, it's not difficult." (1) }\end{array}$ & OBS7 \\
\hline $\begin{array}{l}5 \text { Provide for compatibility across } \\
\text { commonly used accessories } \\
\text { (boxes). }\end{array}$ & $\begin{array}{l}\text { "but it is trying to fit it in the box and sometimes } \\
\text { when you put the lid down, the collar gets } \\
\text { displaced and the alarm will go off" (26) }\end{array}$ & OBS8 \\
\hline $\begin{array}{l}6 \text { Control the contents of the } \\
\text { device. }\end{array}$ & $\begin{array}{l}\text { "when I first started back in } 2008 \text { we had the... the } \\
\text { [pump] had just been removed because of an } \\
\text { incident that just happened. There was some } \\
\text { suggestion that the family had tampered with the } \\
\text { device and because of that, because they weren't in } \\
\text { lockable boxes, they were removed" (18) }\end{array}$ & OBS9 \\
\hline
\end{tabular}




\begin{tabular}{|c|c|c|}
\hline Recommendation & Quotation & REF \\
\hline $\begin{array}{l}7 \text { When the device is used within } \\
\text { a lockbox, ensure that the design } \\
\text { remains appropriate for an } \\
\text { ambulatory context. }\end{array}$ & $\begin{array}{l}\text { "It is just basically they find it a little bit bulky } \\
\text { carrying it around... Especially [the] lockbox..." } \\
\text { (14) }\end{array}$ & OBS10 \\
\hline $\begin{array}{l}8 \text { Ensure the means to open / } \\
\text { shut the lockbox is readily } \\
\text { available for those who require } \\
\text { access. }\end{array}$ & $\begin{array}{l}\text { "This is the plastic, there's a lockable case, which is } \\
\text { good in one way, but of course, you know, you } \\
\text { have concerns about where's the key. So in my } \\
\text { particular area, we bought the different coloured } \\
\text { tags to put on the keys, like orange, and we said } \\
\text { we'd keep it in the front of the [location]. Other } \\
\text { areas have actually taped it to the [location]. It's } \\
\text { making sure that everybody knows where this key } \\
\text { is." (26) }\end{array}$ & OBS 11 \\
\hline $\begin{array}{l}9 \text { If the device is used with } \\
\text { accessories such as a lockbox } \\
\text { make sure that they are soft and } \\
\text { robust whilst at the same time } \\
\text { providing for quick and easy } \\
\text { access. }\end{array}$ & $\begin{array}{l}\text { "...apart from the casing like I said, the plastic } \\
\text { casing, the outer casing is quite brittle and } \\
\text { sometimes you have a little struggle with the keys } \\
\text { to get them... To open it properly, you know you're } \\
\text { fighting against it and they snap the inner little } \\
\text { plastic bit that links it, closes it. Those will... snap } \\
\text { off... Yes, and if someone, if a patient drops them, } \\
\text { which they will do, if they're fidgeting about they } \\
\text { will drop it, that will just break." (5) }\end{array}$ & OBS12 \\
\hline $\begin{array}{l}10 \text { For a device that contains } \\
\text { security controls consider how } \\
\text { such controls will work in the } \\
\text { home environment (e.g. when the } \\
\text { device is left alone). }\end{array}$ & $\begin{array}{l}\text { "we usually have a key and a spare in the bag and I } \\
\text { can't remember if we ever had a key in the office, } \\
\text { or whether we just left them with the patient. But } \\
\text { they are left in the bag and generally speaking the } \\
\text { patients don't touch the bag because that's got the } \\
\text { drugs in it, and the key and a spare battery." (7) }\end{array}$ & OBS13 \\
\hline $\begin{array}{l}11 \text { For a device that contains } \\
\text { security controls provide the } \\
\text { option to override the system in } \\
\text { event of a mishap. }\end{array}$ & $\begin{array}{l}\text { "I mean the lockbox occasionally causes a problem } \\
\text { if we lose the key" (16) }\end{array}$ & OBS14 \\
\hline
\end{tabular}




\section{Discussion}

In the contexts that were observed only one type of device is being used. This is because the selection process constrains the type of device that can be purchased. In order to buy the device it has to be CE marked and the manufacturer/distributor needs to go through a number of checks. A series of evaluation criteria are applied and the device is excluded if it fails certain checks. The culmination of the above is that all care providers use the same device (see (Vincent and Blandford, 2017) for a detailed explanation).

Despite a single make of syringe driver being used across palliative care, adaptation has occurred to overcome a range of issues. This has implications for the design and use of medical technology. It highlights the need for constant review and customisation. For procurement this means that rather than considering the introduction of equipment at a single point in time, analysis and monitoring needs to occur across the lifecycle.

In healthcare the concept of adaptation (or workaround) is commonly regarded negatively (Halbesleben, 2010). It creates a tension between an outlook that describes such behaviour as an "error", "violation" or "deviation" versus one that views such behaviours as "innovations" or "improvisations" (Debono et al., 2013). Given this tension, there are different perspectives on the benefit that adaptation provides. Randell touches on this in her study of alarm settings in an Intensive Care Unit (ICU) (Randell, 2003). She explores the reasons behind adaptations and why they might not be viewed positively. In particular, the design, manufacture and use of medical equipment is regulated and the procedures surrounding equipment defined; changing the behaviour of equipment in a local context risks violating assumptions made during design, where "normal" conditions of use are defined. Not using technology in this way (implicit in adaptation), may impact the safety and performance of a system. Some of the time this is beneficial (i.e. providing for flexibility); at other times it presents risk, either within the immediate context or more broadly within the system. Similar issues arise in many medical contexts.

This means that the traditional approach of optimising workflow across a system can only go so far in establishing efficiency, effectiveness and satisfaction. Models such as SEIPS recognise the need for "job balance" i.e. considering interactions between people, organisations, technology, tasks and the environment. The medical device design model by Sharples (2012) includes examples of "adjustability" as a facilitator (of positive consequences); however, the regulated nature of medical device development limits the extent to which this can occur (Vincent and Amalberti, 2016).

This study of syringe driver use highlights a need for customisation and adaptation. It reflects the tension between a top down approach to equipment management (i.e. a single type of equipment constrains the way in which staff 
work) and a socio-technical approach where the form of technology can be variable (i.e. joint optimisation between groups, tools and the environment). Elsewhere, these differences are referred to as "work as imagined" and "work as done" (Blandford et al., 2014; Hollnagel, 2015). The first approach is a designed organisation where rules, regulations and structures reduce the need for human judgment. In this case there are advantages to a syringe driver being inflexible. The second approach allows the organisation to co-evolve with technology to reach a jointly optimised solution (in which case there is a benefit to technology providing for a degree of flexibility). The study reported here shows that a standardised and mandated tool fails to deliver against the need of users when their needs vary considerably. For this reason the second approach is required.

\section{Conclusion}

These findings emphasise the need for a fluid relationship between technology and organisation. In the domain that was studied, like others, adaptation was happening in a collaborative sense. The same technology, ostensibly being used for the same purpose - i.e., palliative care - was adapted differentially in the different contexts of use; this highlights the importance of the social circumstances surrounding technology use, as discussed by Barley (1986). In this view, technology is treated as a social object rather than a physical one, and is conceptualised as a process rather than an entity. This means that adaptations are recognised in a local context and there is a drive to understand repercussions across the broader system (both social and technical). As discussed above, such adaptive behaviours come with both risks and benefits, but they are a necessary component of the successful introduction of technology. This study has particularly highlighted many of the challenges inherent in introducing a safetycritical medical device into the home context, where the dignity, comfort and safety of the patient all need to be considered, and where trained professionals are not immediately on hand to oversee use and intervene if anything untoward occurs. The adaptations presented above highlight an opportunity to review the various needs of patients, families and professionals across contexts, but particularly in the less controlled context of the patient's home. This will be of growing importance as more care shifts to less medicalised contexts (e.g., from hospital to home). 


\section{Conflict of Interest Statement}

Employment: The first author is currently employed by product and service design innovation consultancy PDD Group Ltd.

\section{Acknowledgments}

We would like to thank all of those who have been involved in the research presented in this paper, including all study participants and research nurses. This study was conducted within the CHI+MED project, supported by the UK Engineering and Physical Sciences Research Council [EP/G059063/1].

\section{References}

Amble, N., 2013. Autonomy and Control when Working with Humans-A Reflection on Sociotechnical Concepts. 2013 3, 18.

Barley, S.R., 1986. Technology as an occasion for structuring: evidence from observations of CT scanners and the social order of radiology departments. Adm Sci Q 31, 78-108.

Bikson, T.K., Eveland, J.D., 1996. Groupware implementation: reinvention in the sociotechnical frame, Proceedings of the 1996 ACM conference on Computer supported cooperative work. ACM, Boston, Massachusetts, USA, pp. 428-437.

Blandford, A., Furniss, D., Vincent, C., 2014. Patient safety and interactive medical devices: Realigning work as imagined and work as done. Clinical Risk 20, 107110.

Braun, V., Clarke, V., 2006. Using thematic analysis in psychology. Qualitative Research in Psychology 3, 77-101.

Cafazzo, J.A., Casselman, M., Hamming, N., Katzman, D.K., Palmert, M.R., 2012. Design of an mHealth App for the Self-management of Adolescent Type 1 Diabetes: A Pilot Study. J Med Internet Res 14, e70.

Carayon, P., 2009. The Balance Theory and the Work System Model ... Twenty Years Later. International Journal of Human-Computer Interaction 25, 313-327.

Carayon, P., Schoofs Hundt, A., Karsh, B.-T., Gurses, A.P., Alvarado, C.J., Smith, M., Flatley Brennan, P., 2006. Work system design for patient safety: the SEIPS model. Quality and Safety in Health Care 15, i50-i58.

Carayon, P., Smith, M.J., 2000. Work organization and ergonomics. Appl Ergon 31, 649662.

Carayon, P., Wetterneck, T.B., Rivera-Rodriguez, A.J., Hundt, A.S., Hoonakker, P., Holden, R., Gurses, A.P., 2014. Human factors systems approach to healthcare quality and patient safety. Appl Ergon 45, 14-25.

Cook, R.I., Woods, D.D., 1996. Adapting to new technology in the operating room. Hum Factors 38, 593-613.

Costello, J., Nyatanga, B., Mula, C., Hull, J., 2008. The benefits and drawbacks of syringe drivers in palliative care. International journal of palliative nursing 14, 139-144. 
Cruickshank, S., Adamson, E., Logan, J., Brackenridge, K., 2010. Using syringe drivers in palliative care within a rural, community setting: capturing the whole experience. International journal of palliative nursing 16, 126-132.

Debono, D.S., Greenfield, D., Travaglia, J.F., Long, J.C., Black, D., Johnson, J., Braithwaite, J., 2013. Nurses' workarounds in acute healthcare settings: a scoping review. Bmc Health Services Research 13.

Furniss, D., Masci, P., Curzon, P., Mayer, A., Blandford, A., 2015. Exploring medical device design and use through layers of Distributed Cognition: How a glucometer is coupled with its context. Journal of Biomedical Informatics 53, 330-341.

Gasser, L., 1986. The integration of computing and routine work. ACM Trans. Inf. Syst. 4, 205-225.

Graham, F., Clark, D., 2005. The syringe driver and the subcutaneous route in palliative care: the inventor, the history and the implications. Journal of pain and symptom management 29, 32-40.

Guest, G., Bunce, A., Johnson, L., 2006. How Many Interviews Are Enough?: An Experiment with Data Saturation and Variability. Field Methods 18, 59-82.

Halbesleben, J.R., 2010. The role of exhaustion and workarounds in predicting occupational injuries: a cross-lagged panel study of health care professionals. Journal of occupational health psychology 15, 1-16.

Hollnagel, E., 2015. Why is work-as-imagined different from work-as-done?, in: Wear, R., Hollnagel, E., Braithwaite, J. (Eds.), Resilience Health Care: The resilience of everyday clinical work. Volume 2. Ashgate, pp. 249-264.

Koppel, R., Wetterneck, T., Telles, J.L., Karsh, B.T., 2008. Workarounds to barcode medication administration systems: their occurrences, causes, and threats to patient safety. J Am Med Inform Assoc 15, 408-423.

Mackay, W.E., 1990. Users and customizable software: A co-adaptive phenomenon. Citeseer.

McCormack, P.J., Cooper, R., Sutherland, S., Stewart, H., 2001. The safe use of syringe drivers for palliative care: an action research project. International journal of palliative nursing 7, 574-580.

Money, A.G., Barnett, J., Kuljis, J., Craven, M.P., Martin, J.L., Young, T., 2011. The role of the user within the medical device design and development process: medical device manufacturers' perspectives. Bmc Medical Informatics and Decision Making 11.

NPSA, 2010. Rapid Response Report: Safer Ambulatory Syringe Drivers in: NPSA (Ed.). NPSA, London.

O'Kane, A.A., Rogers, Y., Blandford, A.E., 2015. Concealing or Revealing Mobile Medical Devices?: Designing for Onstage and Offstage Presentation, Proceedings of the 33rd Annual ACM Conference on Human Factors in Computing Systems. ACM, Seoul, Republic of Korea, pp. 1689-1698.

Obradovich, J.H., Woods, D.D., 1996. Users as designers: how people cope with poor HCI design in computer- based medical devices. Human Factors 38, 574-592.

Oliver, D., 1988. Syringe drivers in palliative care: a review. Palliative Medicine 2, 21-26.

Randell, R., 2003. User customisation of medical devices: the reality and the possibilities. Cognition, Technology \& Work 5, 163-170.

Rogers, Y., 1994. Exploring obstacles: integrating CSCW in evolving organisations, Proceedings of the 1994 ACM conference on Computer supported cooperative work. ACM, pp. 67-77. 
Sharples, S., Martin, J., Lang, A., Craven, M., O’Neill, S., Barnett, J., 2012. Medical device design in context: A model of user-device interaction and consequences. Displays 33, 221-232.

Smith, M.J., Carayon, P., 1989. A balance theory of job design for stress reduction. International Journal of Industrial Ergonomics 4, 67-79.

Trist, E.L., Bamforth, K.W., 1951. Some Social and Psychological Consequences of the Longwall Method of Coal-Getting. Human Relations 4, 3-38.

Trist, E.L., Higgin, G.W., Murray, H., Pollock, A.B., 1963. Organizational choice : capabilities of groups at the coal face under changing technologies. Tavistock Publications, [S.l.].

Vincent, C.J., Blandford, A., 2017. How do health service professionals consider human factors when purchasing interactive medical devices? A qualitative interview study. Applied Ergonomics 59, Part A, 114-122.

Vincent, C.J., Li, Y., Blandford, A., 2014. Integration of human factors and ergonomics during medical device design and development: It's all about communication. Applied Ergonomics 45, 413-419.

Vincent, C., \& Amalberti, R. (2016). Safer healthcare. Cham: Springer International Publishing.

Watson, M., Sanderson, P., John Russell, W., 2004. Tailoring reveals information requirements: the case of anaesthesia alarms. Interacting with Computers 16, 271-293.

West, C., 2014. The use of syringe drivers in the community: considerations for palliative care providers. International journal of palliative nursing $20,56,58-59$. 


\section{Supplementary data}

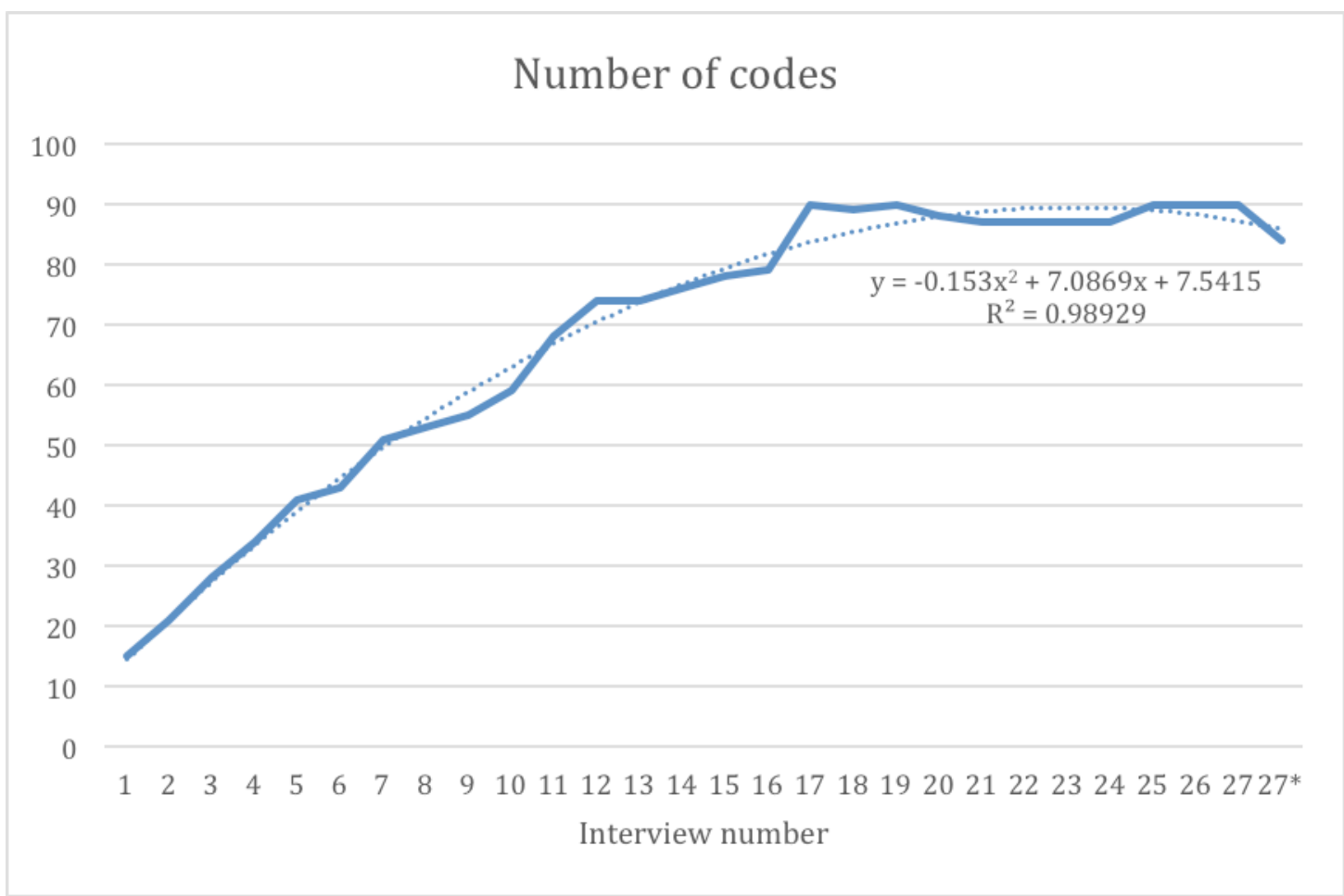

\begin{tabular}{|l|l|l|}
\hline Name of code & Occurrences & Category \\
\hline $\begin{array}{l}\text { Organisation and experience (advice and } \\
\text { support] }\end{array}$ & 76 & General background \\
\hline [Syringe driver] is good / easy to use & 54 & General background \\
\hline Overlap with other equipment & 47 & Security of the device \\
\hline Lockbox and lockbox issues & 40 & Security of the device \\
\hline Training & 37 & - \\
\hline What the syringe driver is used for & 31 & General background \\
\hline Involvement in purchasing & 29 & - \\
\hline Transitions & 25 & - \\
\hline Frequency of use & 23 & General background \\
\hline Keys, locks and keypad locks & 22 & Security of the device \\
\hline Batteries & 19 & $\begin{array}{l}\text { Device and } \\
\text { accessories }\end{array}$ \\
\hline Overlap with prescribing practice & 18 & General background \\
\hline Patient / family perspective & 16 & Device and patient \\
\hline Size and weight & 14 & Device and patient \\
\hline Syringes & 14 & $\begin{array}{l}\text { Device and } \\
\text { accessories }\end{array}$ \\
\hline Portability and bags & 13 & Device and patient \\
\hline
\end{tabular}




\begin{tabular}{|l|l|l|}
\hline What the [syringe driver] is called & 13 & General background \\
\hline Aesthetics & 11 & Device and patient \\
\hline Trialling of equipment & 10 & - \\
\hline Workflow & 10 & General background \\
\hline Alarms & 9 & Device and patient \\
\hline Home care versus hospital care & 9 & General background \\
\hline Safety & 9 & General background \\
\hline Overlap with paper based systems & 8 & - \\
\hline Tracking of equipment & 8 & - \\
\hline Cost & 7 & - \\
\hline Need for reliability & 7 & Device and patient \\
\hline Resource & 7 & - \\
\hline Checking & 6 & - \\
\hline Connections with the frontline & 6 & General background \\
\hline Only the [syringe driver] is available & 6 & - \\
\hline Other accessories & 6 & Device and \\
\hline Accuracy & & accessories \\
\hline Not involved in purchasing & 5 & - \\
\hline Encouraged to adopt & 5 & - \\
\hline Old equipment worse & 4 & - \\
\hline Reasons for procurement & 4 & General background \\
\hline Resistance to change & 4 & General background \\
\hline Systems & 4 & - \\
\hline Unpredictability & 4 & - \\
\hline Inflexibility & 4 & - \\
\hline Quick reference guide / manual & 3 & - \\
\hline Timescales on introduction & 3 & - \\
\hline Unexpected behaviour of device & 3 & - \\
\hline Availability of equipment & 3 & - \\
\hline Calibration / servicing & 2 & - \\
\hline Device log & 2 & - \\
\hline Discrete equipment & 2 & - \\
\hline Environmental considerations & 2 & Device and patient \\
\hline Improvements & 2 & - \\
\hline Multi disciplinary teams & 2 & - \\
\hline Off label use & 2 & - \\
\hline Reliability & 2 & - \\
\hline Safety v usability & & - \\
\hline The pump gets dropped & 2 & - \\
\hline Use of instruction manual / \\
documentation & 2 & \\
\hline
\end{tabular}




\begin{tabular}{|l|l|l|}
\hline Advice and support & 1 & - \\
\hline Avoiding complexity & 1 & - \\
\hline Committees & 1 & - \\
\hline Consent & 1 & - \\
\hline Continuity & 1 & - \\
\hline Cost v preference & 1 & - \\
\hline Despite issues staff like the equipment & 1 & - \\
\hline Fiddly & 1 & - \\
\hline Flawed assumptions & 1 & - \\
\hline Flexibility & 1 & - \\
\hline Forced introduction & 1 & - \\
\hline Growing responsibility of nurses & 1 & - \\
\hline $\begin{array}{l}\text { Information that the pump should } \\
\text { provide }\end{array}$ & 1 & - \\
\hline Lack of interest & 1 & - \\
\hline Lack of training & 1 & - \\
\hline Letters of recommendation & 1 & - \\
\hline Logs & 1 & - \\
\hline Misunderstanding regarding function & 1 & - \\
\hline Multiple pumps for one patient & 1 & - \\
\hline Needle free devices & 1 & - \\
\hline Out of hours support & 1 & - \\
\hline Potential for error & 1 & - \\
\hline Purchasing provides the wrong stuff & 1 & - \\
\hline $\begin{array}{l}\text { Purchasing - going beyond a single point } \\
\text { in time }\end{array}$ & 1 & - \\
\hline Purchasing broader than equipment & 1 & - \\
\hline Reduce dependency on manufacturer & 1 & - \\
\hline Relationship with manufacturer & 1 & - \\
\hline Trainer as a mediator & 1 & - \\
\hline & & \\
\hline
\end{tabular}

